\title{
Kaliningrad: A Dual Shift in Cooperation and Conflict
}

Anna-Sophie Maass, Lecturer in International Relations and Diplomacy, Lancaster University, a.maass@lancaster.ac.uk

\begin{abstract}
Around Poland's accession to NATO in 1999, Russian-NATO relations started to deteriorate. A similar contestation occurred in anticipation of the EU's eastern enlargement in 2004 when the transit of Russians to and from Kaliningrad was the most contentious topic in EU-Russian diplomacy. More than a decade later, Kaliningrad is not on the agenda of EU-Russian relations anymore. Instead, it is Russia's deployment of missiles in Kaliningrad that has become a severe security concern for Europe and NATO, which regard the Baltic States' proximity to the missiles as a threat for European security.

This article argues that NATO's security concerns about Kaliningrad has replaced EU-Russian contestation about visa liberalisation as the main source of conflict in relations between Brussels and Moscow. It will be demonstrated that the case of Kaliningrad reflects a dual shift: from a contested to a fluid boundary in EU-Russian relations, and from a contested to a solid boundary in NATO-Russian relations. This article further elucidates the emerging competition between the EU and NATO over security threats in Kaliningrad between 2013 and 2018 - a shift of arenas of conflict from EU-Russia to NATO-Russia.
\end{abstract}

Keywords: EU, NATO, Kaliningrad, nuclear missiles, Russia, security

Word count: 7780 words

\section{Introduction}

With the double eastern enlargement Kaliningrad became a contentious topic in both EURussian and NATO-Russian relations. Poland's accession to NATO in 1999 followed by Lithuania's in 2004 which coincided with their accession to the EU, resulted in the Russian exclave's encirclement by EU and NATO territory. At the time the military security situation was known to be problematic, as NATO was starting to be the object of strategic contestation by Russia. Regarding human transit, the inclusion of Poland and Lithuania in the Schengen area had a tangible impact for citizens travelling between Russia and Kaliningrad. Seeking to regulate transit the European Commission introduced facilitated transit documents which 
members of the Russian political elite condemned as infringements of the right of the free movement of persons (Maass, 2017).

More than a decade after this denunciation, Kaliningrad is not a contentious issue in EU-Russian relations anymore. However, Russia's deployment of nuclear missiles in the exclave has intensified already existing security concerns for the US, NATO and the Baltic States. Russia's stationing of missiles and its suspension from its membership in the Consultative Group of the Treaty of Conventional Armed Forces in Europe signed in 1990 aimed at limiting weaponry (Tass, 2015) are recent examples of lacking 'checks and balances' in the European security system. According to Richard Sakwa, there was a "failure to create a mutually acceptable European security system" since the end of the Cold War (Kempster in Sakwa, 2015). This lacking post-Cold War security architecture was compounded by "systemic tensions" between Russia's and the West's political systems, "values issues, incompatible identities, struggles for hegemony, institutional inertia and differing visions of the future [...]." (Sakwa, 2015). The Ukraine crisis, the deployment of missiles in Kaliningrad and the open Ukrainian-Russian confrontation in the Sea of Azov in November 2018 fanned fears in Europe regarding the possibility of war.

This article examines Kaliningrad as a border-zone of contact where cooperation and conflict fluctuated between the EU, Russia and NATO in order to elucidate both the emergence and implications of the latest security threats stemming from the oblast. So far Kaliningrad as a border region resulting in shifts from EU-Russian to NATO-Russian contestation has not been assessed in academic literature. Anke Schmidt-Felzmann examined how Kaliningrad became sidelined on the agenda of EU-Russian relations after their initial cooperation in seeking to 'prevent soft security threats stemming from the exclave of gaining an upper hand' (Schmidt-Felzmann, 2018). In this vein, her article touches upon the EU-Russian diplomacy regarding Kaliningrad and is complemented by Grønbjerg's (2018) assessment of EU-Russian 
contestation over visa-free travel to and from the exclave. Therefore, Schmidt-Felzmann's and Grønbjerg's work complement the analysis of EU-Russian diplomacy over Kaliningrad addressed in the first section of this article. However, their work does not intend to explain the shift from EU-Russian tensions to NATO-Russian contested engagement over the exclave, which is at the core of this article. Other scholarly accounts on Kaliningrad assessed visa-free transit, such as Baxendale's assessment of the progress regarding EU-Russian discourse on Kaliningrad in 2001, Aalto's examination of EU-Russian cooperation "creating order to the Kaliningrad region" and Holtom's analysis of the transit of people between 2002 and 2004 (Holtom, 2005, p. 45; Aalto, 2002; Baxendale, 2001). Domaniewski's and Studzińska's assessment of the Polish-Russian visa free agreement regarding Kaliningrad is complementary to Holtom's account (2016). By contrast, Vinokurov assesses "political and economic vulnerabilities" stemming from Kaliningrad's unique geographic location (2005). In a similar vein, Diener and Hagen contend that Kaliningrad faces several problems in the economy and in inter-state relations (2011).

This article exceeds the scope of the above-mentioned examinations. It analyses whether and how cooperation and conflict co-exist in Europe-Russian relations over Kaliningrad. It argues that EU-Russian contention over human transit in Kaliningrad in 2002 was replaced as the main flashpoint for conflict by NATO-Russian contestation over the stationing of Iskander missiles in the oblast. In seeking to examine the coexistence of cooperation and conflict and their divergent effects on EU-Russian and NATO-Russian relations in the border zone of Kaliningrad, this article adopts the same approach as the special issue by focusing on symbolic boundaries. The latter are understood as "principles of vision and division" (Bourdieu, 1989) that distinguish the self from the other, the neighbour from the alien, and the allied from the enemy (Mérand and Dembinska, Introduction to this Special Issue). 
The conceptual purpose of this article is to demonstrate that symbolic boundaries between Europe and Russia around Kaliningrad have evolved over the past two decades. Initially the symbolic boundaries that emerged from Kaliningrad's double encirclement in 2004 when the Baltic States joined the EU and NATO could be characterized as contested. 15 years later the symbolic boundary between the EU and Russia has become more fluid, implying that a distinction between the "self" and the "other" is in flux implying a transformation of this symbolic boundary. According to Domaniewski and Studzińska, "not all borders conform to a traditional or rationally coherent set of norms" or a "set of fixed policies applied to them", as was the case with Kaliningrad due to Russia's, the EU's and NATO's divergent political and military approaches in their engagement with the oblast (2016, p. 638). It is in light of these actors' engagement with Kaliningrad that the article argues that a dual shift regarding this boundary occurred, namely from a fluid boundary which manifested itself in an EU-Russian dialogue over visa-free travel to a solid boundary in NATO-Russian engagement. As a consequence no direct interaction took place between Russia and NATO but their interests over the oblast remained divergent. For Russia, Kaliningrad remained a prime location for certain military operations but for NATO the stationing of Russian nuclear missiles embodied a potential security threat.

The shift from Kaliningrad as a fluid boundary between the EU and Russia to a solid boundary between Russia and NATO was shaped by two factors. First, the end of the Cold War resulted in a new constellation of actors with varying political, economic and military clouts shaping their roles in contemporary international politics. Second, the EU's security policy had only recently been institutionalised by the launch of the post of the High Representative for the Common Foreign and Security Policy in 1999 (Maass, 2017). As a result, the EU was not yet prepared to assume responsibilities due to its lacking capacities in security and defence policies. In order to address this shortcoming, the EU's enhanced cooperation with NATO was 
required to deal with increasing security concerns stemming from Kaliningrad as this paper will demonstrate. It assesses the actors' approaches towards these changing symbolic boundaries on the one hand and examines the resulting effect on Russia's engagement with the EU and NATO over Kaliningrad on the other hand.

The article begins with setting the conceptual framework before describing the EURussian dilemma over Kaliningrad. It continues with assessing the rationale underpinning Russia's deployment of missiles in Kaliningrad and the EU's and NATO's approaches on this issue. Foreign policy analysis with process tracing was chosen as a methodology to allow for an analysis exceeding domestic boundaries (Hill, 2003) in light of the multiple actors whilst accounting for shifts over both issue areas and time. The analysis begins with the EU-Russian contestation over visa-free travel in 2004 before addressing the increasing confrontation between NATO and Russia in 2018.

\section{The Fluidity of Evolving Borders in the Case of Kaliningrad}

Prior to NATO's and the EU's eastward expansion, Kaliningrad was a contested boundary which was marked not only by strategic rivalry with NATO but also by the absence of an EURussian mutual agreement over transit regulations to and from the exclave. The result was a lengthy dispute over the issue which will be discussed in the following section. For the EU, this contested boundary evolved into a fluid boundary marked by temporary cooperation regarding transit regulations to and from Kaliningrad. But for NATO, there was a shift to a solid boundary characterised by the concern to maintain security in the aftermath of the stationing of Iskander missiles in Kaliningrad. A dialogue with Russia on the deployment of nuclear missiles remains highly contentious and is marked by polar-opposite views. However, the result of this lacking dialogue is not a direct but rather a frozen conflict which could boil to the surface as was exemplified by the open Ukrainian-Russian confrontation in the Sea of Azov 
in November 2018 (Maass, 2019). Only time will tell whether cooperation or conflict will gain the upper hand in the fluid boundary in Kaliningrad in the medium to long-term. This assessment on the evolution of boundaries in the case of Kaliningrad shows that while some boundaries may become fluid and ease cooperation, this process can go alongside a hardening of other boundaries that leads to conflict as the following section on EU-Russian contestation over visa free travel in Kaliningrad will demonstrate.

\section{The EU-Russian Diplomacy on Kaliningrad}

For almost two decades, Kaliningrad was on the agenda of EU-Russian relations to varying extents. At the EU-Russia summit in autumn 1999 Prime Minister Vladimir Putin reiterated that Kaliningrad shall become a 'pilot project' of EU-Russian cooperation, withstanding that an agreement safeguarding Kaliningrad's interests as part of the Russian Federation in light of the EU's eastern enlargement was to be concluded (Karabeshkin \& Wellmann, 2004, p. 25). However, such an agreement has not been adopted and is one of the main reasons why the idea of the pilot project did not materialise.

From a political point of view, the status of Kaliningrad as a pilot project could have resulted in a "reciprocal and open strategic partnership" between the EU and Russia. From an economic point of view, Kaliningrad's modernisation entails the application of 'institutional, technical and social standards which are new for Russia but routine for the EU' (Karabeshkin \& Wellmann, 2004, p. 58). Karabeshkin and Wellmann denounce the idea of the pilot region as a "public relations activity, due to the lack of a concept supporting this idea accompanied by President Yeltsin's weakened support: The [idea of the pilot project reflected] [..] Russia' [s] [willingness] for cooperation with the EU" whilst agreeing to add issues on their joint agenda which were previously considered as Russian domestic affairs" (Ibid., p. 59). 
About a year after the deliberations on this pilot region, a lengthy debate over Kaliningrad marked EU-Russian relations after Poland's and Lithuania's accession to the EU resulted in Kaliningrad's enclosure within EU territory. As a consequence residents wishing to travel between Kaliningrad and Russia had to cross EU territory. Poland's and Lithuania's accession to the Schengen zone required Russian citizens travelling to and from Kaliningrad to obtain visas given that they crossed an EU border. In an attempt to regulate this transit of people the European Commission introduced a facilitated transit document (FTD), which was comparable to a visa. Members of the Russian political elite directed vociferous condemnations against the EU claiming that this introduction of the FTDs was an infringement of the right of the free movement of persons (Maass, 2017).

According to Forsberg and Haukkala, Russia sought to facilitate visa liberalisation with the EU. At the EU-Russia summit in St Petersburg in May 2003 visa liberalisation was mentioned as a "long-term perspective" (Forsberg \& Haukkala, 2016, p. 139). Despite European Commission President Romano Prodi's promise that this liberalisation could be implemented within five years no concrete date was set (Ibid.). Five years later after the idea of the visa liberalisation was uttered, Russian Foreign Minister Sergei Lavrov expressed Russia's readiness for visa liberalisation, but the EU considered this to be an objective, which had to be met by a concrete schedule and a series of reforms by Russia. Several measures aimed at facilitating visa policies were implemented, such as the EU-Russian Visa Facilitation Agreement which entered into force in June 2007. This agreement also introduced 'privileged categories' of citizens who could obtain visas by providing less documents supporting their application. The Visa Free Dialogue aimed at paving the way to visa-free short-term travel without implying an 'automatic right for visa free travels' (Ibid., p.141).

During the preparations for the Olympic winter games in Sochi in February 2014, Russia undertook a renewed attempt to achieve visa freedom. Lavrov stated that from a practical point 
of view the EU and Russia would be ready to implement visa liberalisation but regretted that the failure to introduce it was "symbolic, exemplify[ing] all the differences between the EU and Russia" (Forsberg \& Haukkala, 2016, p. 144). The EU's imposition of freezing of the visa free regime in March 2014 was among the first series of sanctions implemented against Russia after its annexation of Crimea. It was the nail in the coffin of the dialogue on visa liberalisation (Ibid., p. 145).

Meanwhile the contentious issue of EU-Russian visa-free travel moved to cooperation on a bilateral level involving Poland and Russia. A "simplified border crossing procedure", which entered into force in July 2012 was a testing ground for visa-abolition between Russia and the EU (Tass, 2012). According to the Polish Foreign Minister Radoslaw Sikorski this agreement "will facilitate the speediest introduction of visa-free travel between Russia and the EU" (Ibid.). He reiterated his wish by stating that it was in Poland's "interest [...] that the Kaliningrad region $[\ldots]$ become[s] a gateway to Russia for the EU and a trade gateway to stronger ties with the [EU] for Russia" (Ibid.). About a month after the agreement's establishment about 2000 Polish citizens submitted applications for visa-free travel to Russia's exclave (Tass, 2012 b). Once a permission is granted, the applicant can stay in Kaliningrad up to ten days (Ibid.). Initially people living at the Polish-Russian border can travel freely for two years, a period which can be extended to five years for $20 €$ (Domaniewski, S. and Studzińska, D. 2016, p. 544). Even though border crossings quadrupled in 2012 as compared to 2009 (Ibid., p. 545), Sikorski's aspirations were not fulfilled. On the contrary, in July 2016 the Polish government temporarily annulled this agreement, due to security issues linked to the NATO summit taking place in Warsaw and the Pope's stay in Krakow (European Parliament, 2016).

The evolution of the Ukraine crisis and the related worsening of EU-Russia relations compounded this agreement's abolition (Domaniewski \& Studzińska. 2016, p. 543). When asked about the Polish government's intention to abrogate the agreement, an official working 
at the Russia division of the European External Action Service (EEAS) stated that the Service cannot comment on bilateral agreements with third states. This official explained that the opportunity for the agreement was created by the EU Local Border Traffic Regulation, an adapted regulation regarding external border crossings of Schengen states (Interview, 2018; European Commission, 2019). Despite this temporary suspension of the Polish-Russian border agreement, transit across this border continued; thus indicating that the deferral did not have wide-ranging negative repercussions (Zȩgota, 2018).

This assessment on visa-free travel demonstrated that the contentious EU-Russian dialogue was replaced by brief Polish-Russian cooperation on the matter. Thus, concerning the issue of transit, Kaliningrad was a contested boundary in EU-Russian relations yet a fluid boundary in the Polish-Russian visa-free dialogue. The emergence of the Ukraine conflict rendered the border of Kaliningrad rigid, bringing about security risks which are examined in the following section. It can be stated that from a geopolitical perspective, the EU-Russian boundary was rigid but that at the local level cooperation between Russia and Poland took place regarding visa free travel which reflects cooperation as a characteristic of a fluid boundary. The following section addresses Kaliningrad as a border shifting from a contested to a solid boundary in NATO-Russia relations.

\section{The Shifting Discourse on Kaliningrad: From Transit to Security}

The year 2015 witnessed a shift from EU-Russian contestation over transit regulations regarding Kaliningrad to security concerns in NATO-Russian relations. This shift was shaped by Russia's deployment of missiles in Kaliningrad. As a consequence, NATO as well as Lithuania which shares a border with Kaliningrad became increasingly concerned about security threats stemming from the exclave. This section examines the evolution of these concerns. 
Kaliningrad had military importance for Russia as the base for the Russian Navy's Baltic Fleet. The militarisation of the region was perceived as an obstacle to foreign direct investment (Karabeshkin \& Wellmann, 2004, p. 75). In a different vein, Vladimir Yegorov, former Commander in Chief of the Baltic Fleet supported Kaliningrad's militarisation of the Russian enclave. Kaliningrad, he argued, "plays an important role in ensuring Russian national interest in the Baltic and in Europe, as well as in constituting an element of European security. The NATO enlargement to the East further strengthens this role" (Ibid.).

In contrast with Yegorov, Chris Donnelly, former special adviser for Central and Eastern European Affairs at NATO dismissed security concerns of Kaliningrad. He stated that Kaliningrad "no longer features as a classic security concern [...]. The fundamental change in East-West relations may not have resulted in perfectly harmonious relations between the West and Russia but it has completely removed any fear in the West of military confrontations with Russia. Russia is no longer seen as a threat. [...] [T]his has changed the perception of Kaliningrad" (Donnelly in Baxendale, 2000, p. 215). In light of the demilitarisation of Kaliningrad by reducing "serving officers" stationed in the Russian exclave, Donnelly stated in 2000 that there "is no sense at all of the military establishment now being a threat, either to neighbouring states or to the existing social order in Kaliningrad" (Ibid., p. 217). Donnelly's assessment of the reduced security risks stemming from Kaliningrad was legitimate at the time. However, over a decade and a half after his assessment there was a threat perception originating from Kaliningrad due to two reasons.

First, the large-scale military exercises Russia increasingly carried out in its exclave since 2013 became a security concern for the EU and NATO. It was estimated that 9000 soldiers, 55 navy ships and all military aircrafts were deployed in a military drill in 2015 (The Economist, 2015). The Alliance's Secretary General Stoltenberg acknowledged that NATO has been enhancing its "intelligence and better situational awareness" over the past years 
(NATO, 2018) and asserted that NATO will "defend all allies against any threat" (NATO, 2018, a).

Second, the deployment of missile Iskander M in Kaliningrad in October 2016 increased fears about security threats stemming from this Russian oblast. This missile has the capacity of reaching up to $500 \mathrm{~km}$, thus being able to target European capitals such as Riga, Vilnius, Tallinn, Stockholm, Berlin or Warsaw (Sukhankin, 2017). These ten Iskander missiles and the most extensive military exercises Russia carried out with Kaliningrad and Belarus since the end of the Cold War poses a direct threat to NATO and the EU. These drills involved about 100.000 personnel and contributed to an increased threat perception for Lithuania (MacAskill, 2017). About two weeks after Ukraine's abstention from signing an Association Agreement (AA) with the EU in November 2013, Lithuania's President Dalia Grybauskaite stated that "Russia for us is a neighbour that continues to exploit its influence: through its energy policy, through cyber-attacks, by corrupting our political system and exerting influence on our media" (BBC Monitoring Europe, 2013). In April 2015 at an annual security conference taking place in Tallinn, NATO officials and heads of states of the Baltic States discussed the potential threats emanating from Russia, which manifested itself in inter alia flights of military planes in the Baltic airspace. Representatives at the conference were blunt about the Baltic States being on the 'front line' since the emergence of the Ukraine crisis, the lacking post-Cold War security architecture whilst acknowledging that Russia posed the biggest threat to security since the end of the Second World War (Rashid, 2015).

After the deployment of Iskander missiles in Kaliningrad in October 2016 the threat perceived by heads of states and government of the Baltic States increased. Grybauskaite stated that "the neighbour is starting to be aggressive and threatening in the geopolitical sense [...] It is now [...] important to speak about deescalating the situation so that it does not lead to very serious military conflicts" (Baltic News Service, 2016). Lithuania's Foreign Minister Linas 
Linkevicus denounced the deployment of missiles of being in breach of international law due to the capacity of their range (Sims, 2016). Russian Major General Igor Konashenkov dismissed these concerns and explained that this deployment was merely part of a "military exercise (Sims, 2016) [which] is mobile [and] part of the plan of combat training [;] missile troops are engaged in training on a year-round basis covering great distances of the Russian territory in various ways: by air, by sea and under their own power" (Ibid.).

The rationale for the deployment of missiles in the Russian oblast dates back to Dmitrii Medvedev's presidency. In his State of the Nation Address in November 2008 he explained that the stationing of Iskander was being primarily a response to NATO's deployment of warships in the Black Sea. Medvedev claimed that the increasing tensions in the Caucasus stemming from "the Georgian army's attack on Russian peace-keepers" which became widely known as the Russian-Georgian war in August 2008, was used as a "pretext" to undertake this deployment of warships and bring American anti-missile systems to Europe (Medvedev, 2008). These developments "forces Russia to take measures in response" (Ibid). At the same time, he warned that they "destabilised the foundations of the world order" (Ibid). In this context Medvedev refers to measures Russia will undertake to counter "persistent and consistent attempts of the current American administration to install new elements of a global missile defence system in Europe" (Ibid). Medvedev stated that in order to "neutralise the missile defence system Iskander missiles will be deployed in Kaliningrad" (Ibid). One of the reasons underpinning this US-Russian contention over missiles was the US' decision in 2001 to abrogate the Anti-Ballistic Missile Treaty. The rationale of this Treaty signed with the Soviet Union in 1972 was to restrict the US and Soviet Union's missile defence to two to protect the capital and the intercontinental ballistic missile launch area (US Department of State).

Medvedev's explanation regarding the motivation for the deployment of Iskander missiles remained a narrative of Putin's third term as president. Dimitry Peskov, a spokesman for Putin, 
warned that Iskander could be deployed in response to the US positioning of its nuclear weapons in Germany. In this vein, he alluded to a US-German agreement regarding the eventual launch of US nuclear missiles in the event of an attack by Russia on Europe (The Wall Street Journal, 2019). This US-German agreement developed in the context of the US' decision to withdraw from the Intermediate-Range Nuclear Forces Treaty (INF) signed between the US and Russia in 1987. This treaty abolished missiles on land in Europe traveling between 500 and 5,500 km (The Times, 2015). According to Peskov, these US plans were a "serious [step] towards escalation of tensions on the European continent. [...] Hence, Russia will naturally have to take countermoves [and] countermeasures for restoring this strategic balance and parity" (Ibid.). These developments exemplify the scope of US-Russian tensions on the issue of nuclear disarmament.

Russia's and the US' mutual accusations about breaching the INF Treaty do not indicate potential for the development of an emerging cooperative dialogue but instead reflect a contested boundary. On October 242018 President Putin stated that Russia would respond to the stationing of such American missiles with counter-measures (Zeit online, 2018). The development of missile 9M729, which exceeds the limit of the accepted range is considered to be in breach of the treaty (Ibid.). President Putin however, stated that the US had no evidence to proof this contractual violation. In what can be considered a way to distract from accusations against Russia, he accused the US government of having established missile defense systems in Poland and Romania as well as the use of drones which fall under obligations of the treaty (Ibid.).

In addition to the US-Russian tension over the INF, signs of confrontation between Russia and NATO emerged in February 2015. A Russian fighter jet buzzed an US military jet over the Baltic Sea "veering off after coming within twenty feet of causing a mid-air collision" (Rashid, 2015). The actual collision could have resulted in NATO's military response. Since the 
emergence of the Ukraine crisis, the frequency of encounters between Russian and US military jets has increased mainly over the Baltic Sea; thus, increasing risks of military confrontation between Russia and NATO. The presence of Russian fighter jets in Kaliningrad enables a rapid take-off, not allowing the Baltic States sufficient time to prepare for an eventual retaliation. At a time of lingering EU-Russian confrontation over Ukraine, people in the Baltic States are not "frightened" by a "war by design but by accident"; the likelihood of this is being increased by the fact that the electronic transponders which are able to track planes in Russian military jets are usually turned off (Ibid.).

The lack of trust in Russian-NATO relations is also reflected in the latest revision of Russia's former Military Doctrine published in July 2015. It refers to NATO's "danger" to Russia (Oliker, 2015). The "build-up of the power potential of NATO and vesting the alliance with global functions carried out in violation of the rules of international law, bringing the military infrastructure of NATO member countries near the borders of [Russia], including further expansion of the alliance" is listed under "main external military risks" [confronting] Russia (Military Doctrine of the Russian Federation, 2015). In contrast to NATO, the EU is mentioned only once in this military doctrine. In the section referring to Russia's strategies of preventing military conflict, the doctrine states that "equitable dialogue on European security issues with the European Union and NATO" should be maintained (Military Doctrine of the Russian Federation, 2015). However, in practice a dialogue between NATO, Russia and the EU on European security has been difficult due to Russia's and the US' conflicting approaches as exemplified by Russia's stance towards the INF.

The level of hostility in Russian-NATO relations had been previously expressed by Russian Foreign Minister Lavrov. In 2014 in an interview with France 24 he was asked whether Russia intended to suspend ties with NATO, Lavrov asserted that "[w]e don't need to do this because NATO did it for us. [...] They have cut practically all ties between the Alliance and 
Russia" (Tass, 2014). This denunciation of Russian-NATO relations is illustrative of the intensity of the crisis in their relationship. Lavrov's assessment is a reminder of the statement of his predecessor Igor Ivanov, who declared in 1999, whilst NATO was bombing Russia's ally Serbia that "at present Russia's relations with NATO are suspended, but those with the EU continue with an intensive dialogue" (Shevtsov, 1999). In 1999 Russian policy makers perceived NATO as an aggressor, whilst the EU was perceived as a benign actor (Maass, 2017). This change of perception is indicative of the shift of the zones of confrontation between the EU and Russia on the one hand and Russia and NATO on the other hand.

The prevalence of conflict over cooperation in NATO-Russian relations is shaped by the actors' perceived security threats stemming from Kaliningrad. The shift of EU-Russian contestation over transit regulations to NATO's security concerns in the case of Kaliningrad demonstrates a transformation of symbolic boundaries. The symbolic boundary in EU-Russian relations moved from a contested boundary over transit regulations to a fluid boundary where cooperation over this regulation can take place as exemplified by the Polish-Russian agreement. The symbolic boundary in NATO-Russian relations shifted from a contested to a solid boundary which was marked by lacking cooperation over security related aspects stemming from Kaliningrad. However, this lack of cooperation did not imply a perpetual open conflict between NATO and Russia but merely underlying tensions in the relationship. According to the Foreign Policy Concept of the Russian Federation of November 2016, there are more "systemic problems in the Euro-Atlantic region" which "accumulated over the last quarter of the century" (Russian Foreign Policy Concept, 61, p.18). These problems are reflected in both NATO's and the EU's expansion in addition "with their refusal to begin implementation of political statements regarding the creation of a common European security and cooperation framework result[ing] in a serious crisis in the relations between Russia and the Western States" (Ibid.) 
A fragment of the mistrust at the core of Russia's relations with NATO was inherited by the impreciseness of the guidelines of cooperation as stated in the NATO-Russia Founding Act of May 27 1997. This Act launched the Russian-NATO Permanent Joint Council guiding cooperation in peacekeeping, nuclear safety, air traffic control or missile defence, among others (Hill, 2018, p. 136). According to William H. Hill, the Founding Act is a "political commitment, not a formal treaty obligation" (Ibid, p. 137). As a consequence there remains a certain flexibility when it comes to adhering to the Act's guidelines of mutual cooperation. This is also implied by the reference that deployments on the territory of new NATO members was dependent upon the "current and foreseeable security environment" (Ibid), a clause which had been implemented despite US Secretary of State Christopher's assurance at the North Atlantic Council meeting in December 1996 that the Alliance had "no need, no plans and no intentions of extending nuclear deployments in Europe" (Ibid). In addition to NATO's lacking commitment of this promise, its eastward expansion in 1999 was an additional aspect shaping the increasing level of mistrust in NATO-Russian relations before Russia's stationing of nuclear weapons in Kaliningrad further deteriorated the relationship.

Russia's deployment of missiles in Kaliningrad, continuous tensions in Russia's relations with NATO in the wake of the current deadlock in EU-Russian relations pose security risks for Europe in light of a lacking post-Cold War security architecture. According to Sakwa, "between 1989 and 2014 none of the fundamental issues of European security [...] were resolved, provoking the breakdown of 2014", a reference to the Ukraine crisis, the latest example of a security threat stemming from the EU's eastern neighbourhood (2017). Sakwa likens the Ukraine crisis to the "gravest challenge to world peace of our age" (Ibid.). The lacking substitute for such a security architecture creates a vacuum which does not enable Russia, the EU, NATO and the US to create checks and balances at a time of increasing mistrust and enhanced threat perceptions in their relations. In light of Russia's increasingly 
confrontational relations with the Baltic States on the one hand and the US on the other hand, the responsibility for NATO in seeking to guarantee peace has increased since the deployment of Iskander missiles.

The EU's awareness of the urgency to maintain peace in light of the manifold security risks including the Ukraine crisis is reflected in its Global Strategy for the Common Foreign and Security Policy published in July 2016. In its section on European Security order, the strategy holds Russia accountable for the current threats to European security. According to the Strategy, "Russia's violation of international law and the destabilisation of Ukraine, on top of protracted conflicts in the wider Black Sea region have challenged the European Security order at its core" (EEAS, 2016). Surprisingly, the Strategy does not refer to potential threats to security in the Baltic States and in countries within reach of the Iskander missiles. This could presumably be indicative of the fact that the EEAS does consider the presence of the missiles as a primary concern for NATO instead of for the EU due to the latter's inadequate security and defense capabilities.

The deployment of Iskander missiles reflects an ideological confrontation between Russia and NATO. The European Commission's White Paper on the Future of Europe published in March 2017 mentions the prospect of launching a European Defense Union by 2025, achieved through close cooperation with NATO (European Commission, 2017). This intended collaboration cannot be merely traced back to the threats perceived from Kaliningrad but can be considered as a reflection of multiple security concerns the EU faces also in the context of the migration crisis, the struggle against sources of terrorism, continuing conflicts in neighbouring states to its East and its South as well as increasing tensions in Russian-NATO relations.

A further evidence of Russian-NATO tensions is the fact that meetings of the NATORussia Council had not been taking place anymore for two years since Russia's annexation of 
Crimea. Upon its first re-convention on October 31 2018, NATO's Secretary General Jens Stoltenberg stated that NATO "need[ed] to manage a difficult relationship with Russia, meaning that with more military presence [and] exercises, higher tensions, we need to make sure that we prevent incidents, accidents, misunderstanding, miscalculations and if they happen make sure that they don't get out of control" (NATO 2018). His assessment implies the possibility of an intensified conflict between NATO and Russia in the future, which is compounded by the US' and Russia's clash over the INF Treaty. On February 22019 the US informed Russia that it will withdraw from the treaty within six months (US Department of State, 2019). Russia retaliated by withdrawing from the treaty as well (New York Times, 2019). According to Stoltenberg, the problem was that the deployment of "more and more new Russian missiles, missiles capable of carrying nuclear warheads [...] [had] put the INF treaty to jeopardy" (Ibid). For decades the US' policies towards Russia have been shaped by numerous and vociferous pleas for compliance with this treaty and international law. Russia does respond with its own assessment of the situation, which was for instance reflected in the referendum in Crimea or its deployment of missiles in Kaliningrad. For the time being, a more reciprocal development in the form of dialogues on contentious issues in Russia's relations with the EU, the US and NATO is not in sight. As a consequence, there is no guarantee for the perseverance of cooperation over conflict in the short to medium-term which implies that further shifts in symbolic boundaries could take place.

\section{Conclusion}

On an empirical level, this article demonstrated that Kaliningrad has proven to be a case of several boundaries which shaped cooperation and conflict between the EU and Russia as well as between NATO and Russia between 2004 and now. EU-Russian diplomatic relations were tainted by a dispute over transit regulations of Russians to and from Kaliningrad since the 
exclave's inclusion into the EU's territory epitomised by Poland's and Lithuania's EU accession. This contestation was replaced by enhanced cooperation between Russia and the EU over the visa free regulation exemplified by the Polish-Russian transit agreement about a decade after the initial dispute over transit to and from the exclave. NATO-Russian relations, which had been strained by the alliance's eastward expansion in the 1990s, became more conflict-prone since the gradual increase of Russia's deployment of Iskander missiles in the exclave since 2013.

On a conceptual level, this article demonstrated that Kaliningrad mirrors a shift from a contested to a fluid boundary in EU-Russian relations. Simultaneously it also portrays the shift from a contested to a solid boundary in NATO-Russian relations. As a consequence of this shift, the relationship is more prone to conflict given the lack of a security architecture able to guarantee the prevalence of peace in light of the deployment of the Iskander missiles. This lacking security architecture is compounded with the increasing level of mistrust in RussianNATO relations which became strained since both the Alliance's enlargement in the 1990s and its bombing of Kosovo in 1999. This prevalent conflict between NATO and Russia results in tensions at a time when EU-Russia relations already face an extensive crisis since the emergence of the Ukraine conflict.

The examination of the afore-mentioned divergent types of symbolic boundaries in the case of Kaliningrad demonstrates a fluctuation between fluid boundaries easing cooperation and the hardening of boundaries, which could facilitate conflict. The risk of the eruption of such a conflict is enhanced by a lacking post-Cold War security architecture apt at tackling the manifold security challenges at the core of EU-Russia and Russia-NATO relations. The result is a current frozen conflict in Russia's relations with the US, the EU and NATO enhanced by Russia's demonstration of its military capacities in Kaliningrad. The exclave as a playing field 
where Russia, NATO and EU Member States come together is likely to be shaped by fluctuations between conflict and cooperation in the short to medium-term.

This article did not provide an exhaustive analysis of Kaliningrad as a border zone of cooperation and conflict between the EU, Russia and NATO. This multiplicity of actors reflects the "level of analysis" problem of foreign policy analysis requiring the need to transcend analytic shortcomings by exceeding domestic boundaries as a result of an overlap between the domestic and the international level (Hill, 2003). The engagement of multiple actors in Kaliningrad makes this analysis very complex. Thus, future research needs to further examine the evolution of underlying tensions of NATO-Russian relations which were not extensively covered in this article due to evolving contentions of this relationship over issue areas and time. A wider understanding about divergent interests of actors in moments of cooperation or conflict with Kaliningrad would also need to include China's engagement in Kaliningrad, which is exemplified by Russian-Chinese military drills taking place since 2012 (Higgins, 2017). The assessment of the rationale of these operations and its implications for potentially sustained Russian-Chinese cooperation lies beyond the scope of this article. However, potential implications of this cooperation on EU-Russian, US-Russian relations as well as on NATORussian relations will need to be assessed in the near future. 


\section{References}

Aalto, P. 2002. "A European Geopolitical Subject in the Making? EU, Russia and the Kaliningrad " Question." Geopolitics $\quad 7(3)$ 142-174. https://www.tandfonline.com/doi/abs/10.1080/714000977

Baldwin, A. 2016. Power in IR: Analytical Perspectives. In Power and International Relations. A Conceptual Approach. Princeton: Princeton University Press.

Baltic News Service. 2016. "Russia demonstrates aggression, situation shouldn't be escalated - Lithuanian president." October 20, 2016.

Barnett, M. \& Duvall, R. 2005. "Power in International Politics." International Organisation 51(1): 39-75.

Baxendale, J., Dewar, S., \& Gowan, D. (eds). 2000. The EU and Kaliningrad: Kaliningrad and the Impact of EU Enlargement. London: Federal Trust for Education and Research.

Baxendale, J. 2001. "EU-Russia Relations: Is 2001 a Turning Point for Kaliningrad." European Foreign Affairs Review 6(4): 437-464.

BBC 2018. "Trump-Putin summit. Donald Trump and Vladimir Putin holding news conference." Retrieved July 17, 2018 from: https://www.youtube.com/watch?v=3HlYCyJ2znc

BBC Monitoring Europe 2013. Political. Supplied by BBC Worldwide Monitoring. "Lithuanian president says not surprised by Russian pressure on Ukraine." December 3, 2013.

Bourdieu, P. 1989. "Social Space and Symbolic Power.” Sociological Theory 79(1): 14-25.

Diener, A. \& J. Hagen 2011. "Geopolitics of the Kaliningrad Exclave and Enclave: Russian and EU Perspectives." Geopolitics 52(4): 567-592.

Domaniewski, S. and Studzińska, D. 2016. The Small Border Traffic Zone between Poland and Kaliningrad Region (Russia): The Impact of a Local Visa-Free Border Regime. Geopolitics 21(3): 538-555. https://www.tandfonline.com/doi/10.1080/14650045.2016.1176916

European External Action Service 2016. Shared Vision, Common Action, A Stronger Europe: Global Strategy for the European Union's Common Foreign and Security Policy. Retrieved February 22, 2018 from: https://europa.eu/globalstrategy/en/global-strategy-promote-citizensinterests

European Commission 2017. White Paper on the Future of Europe- European Commission. $\begin{array}{llll}\text { Retrieved July } & 31 & 2018 & \text { from: }\end{array}$ https://ec.europa.eu/commission/sites/betapolitical/files/white_paper_on_the_future_of_euro pe_en.pdf

European Commission 2019. Migration and Home Affairs. Local border traffic regime. https://ec.europa.eu/home-affairs/content/local-border-traffic-regime_en 
European Parliament 2016. At a glance. EU-Russia people-to-people contacts. Retrieved May 14, 2019 from: http://www.europarl.europa.eu/RegData/etudes/ATAG/2016/595843/EPRS_ATA(2016)5958 $\underline{43 \text { EN.pdf }}$

Forsberg, T. \& Haukkala, H. 2016. The European Union and Russia. The European Union Series. Palgrave Macmillan.

Grønbjerg, L. (2018). Kaliningrad - A Danger Zone for EU-Russia Relations. In Oldberg, I. (ed). Marketplace or military bastion? Kaliningrad between Brussels and Moscow. UI paper. No. 3. 2018. Published by the Swedish Institute for International Affairs. https://www.ui.se/globalassets/ui.se-eng/publications/ui-publications/2018/ui-paper-no.-32018.pdf

Higgins, A. 2017. "China holds naval drill in Baltic Sea with Russia." The New York Times, July 262017.

Hill, C. 2003. The Changing Politics of Foreign Policy. New York: Palgrave Macmillan.

Holtom, P. 2005. The Kaliningrad test in EU-Russia relations. Perspectives on European Politics and Society 6 (1): 31-54.

Interview 2018. Interview with official working at the Head of the Russia unit, European External Action Service (EEAS). Interview conducted via email. July 312018.

Karabeshkin, L. \& Wellmann, C. 2004. The Russian Domestic Debate on Kaliningrad. Integrity, Identity and Economy. Kieler Schriften zur Friedenswissenschaft. Band 11. New Brunswick and London: Transaction Publishers.

Kempster, N. and Murphy, D. E., 'Broader NATO may bring "cold peace", Yeltsin warns: Europe: Russian President accuses U.S. of being power hungry. Speech comes as nations finalize nuclear treaty', Los Angeles Times, 6 Dec. 1994, http://articles.latimes.com/1994-1206/news/mn-5629_1_cold-war, accessed 5 April 2015. Cited in: Sakwa, R. 2015. Death of Europe? Continental Fates after Ukraine. International Affairs 91(3): 553-579.

Krickus, J. R. 2002. The Kaliningrad Question. Boston Way: Rowman and Littlefield.

Maass, A.-S. 2017. EU-Russia Relations, 1999-2015. From courtship to confrontation. London and New York: Routledge.

Maass, A.-S. 2019. "From Vilnius to the Kerch Strait: Wide-Ranging Security Implications from the Ukraine Crisis." European Politics and Society 20 (5): 609-623. https://www.tandfonline.com/doi/full/10.1080/23745118.2019.1570667

MacAskill, E. 2017. "Russia readies for huge military exercises as tensions with west simmer." The Guardian, August 24.

Military Doctrine of the Russian Federation 2015. The Embassy of the Russian Federation of the United Kingdom of Great Britain and Northern Ireland. Press Releases. Retrieved July 25, 2018 from: https://rusemb.org.uk/press/2029 
NATO 2018. Press Conference by NATO Secretary General Jens Stoltenberg following the morning meeting of the North Atlantic Council (NAC) in Foreign Ministers' session. April 27, 2018. Retrieved July 30, 2018 from: https://www.nato.int/cps/en/natohq/opinions_154092.htm

NATO 2018 a. Press conference by the NATO Secretary General Jens Stoltenberg at the launch of his Annual Report for 2017. 15 March 2018. Retrieved July 30, 2018 from: https://www.nato.int/cps/en/natohq/opinions_152678.htm

New York Times 2019. Russia Pulls Out of I.N.F. Treaty in 'Symmetrical' Response to U.S. Move. Retrieved May 14, 2019 https://www.nytimes.com/2019/02/02/world/europe/russiainf-treaty.html

Oliker, O. 2015. Russia's military doctrine: same as the old doctrine, mostly. Rand Corporation. Retrieved November 8, 2017 from: https://www.rand.org/blog/2015/01/russiasnew-military-doctrine-same-as-the-old-doctrine.html

Rashid, A. 2015. Russia: Twenty feet from war. The New York Review of Books, May 14, 2015. Retrieved November 7, 2017 from: http://www.nybooks.com/daily/2015/05/14/russianato-twenty-feet-from-war/

Russian Ministry of Foreign Affairs. 2016. Comment by the Information and Press Department on Poland's decision to suspend local cross border agreement. July 4 2016. Retrieved February 13, 2018 from: http://www.mid.ru/en/foreign_policy/news//asset_publisher/cKNonkJE02Bw/content/id/2341 $\underline{313}$

Sakwa, R. 2017. "The Ukraine Syndrome \& Europe: Between Norms \& Space.” The Soviet and Post-Soviet Review 44 (1): 9-31.

Sakwa, R. 2015. "Death of Europe? Continental Fates after Ukraine." International Affairs 91 (3): 553-579.

Schmidt-Felzmann, A. (2018). Kaliningrad in EU-Russia Relations - The Neglected Enclave by the Baltic Sea. In Oldberg, I. (ed). Marketplace or military bastion? Kaliningrad between Brussels and Moscow. UI paper. No. 3. 2018. Published by the Swedish Institute for International Affairs. https://www.ui.se/globalassets/ui.se-eng/publications/uipublications/2018/ui-paper-no.-3-2018.pdf

Shevtsov, N. 1999. Vokrug konflikta. Evrosoyiuz - Eto ne NATO. Pul's planety. Trud. May 9 1999.

Sims, A. 2016. "Poland 'highly concerned' after Russia moves nuclear-capable missiles into Kaliningrad; Estonia and Lithuania who have ports on the Baltic Sea have also protested the move." The Independent, October 8.

State of the Nation Address by Russian President Dmitry Medvedev. November 5, 2008. Retrieved May 13, 2019 from: https://www.c-span.org/video/?282252-1/russian-state-nationaddress 
Sukhankin, S. 2017. European Council on Foreign Relations. Kaliningrad: from boom-town to battle station. Retrieved May 12, 2019 from:

http://www.ecfr.eu/article/commentary_kaliningrad_from_boomtown_to_battle_station_7256

Tass. Russian News Agency. July 4, 2016. "Russia suspends Poland-Kaliningrad border traffic agreement-ministry.” Retrieved May 13, 2019 from: http://tass.com/politics/886286

Tass. Russian News Agency 2012. August 23, 2012. "Poland to resume accepting applications for visa-free border crossing with RF."

Tass. Russian News Agency 2012 b. August 27, 2012. "Over 1000 Poles get permits for visafree access to Kaliningrad region."

Tass. Russian News Agency 2014. "Russia has never called NATO and enemyLavrov/updates." December 16, 2014.

Tass. Russian News Agency. 2015. "NATO disappointed with Russia's decision to suspend participation in CFE consultative group - Stoltenberg." March 11, 2015.

The Delegation of the European Union to Russia. The Russian Federation's Middle Term Strategy towards the EU Retrieved November 18, 2009 from: http://www.delrus.ec.europa./en/p_245.htm

The Economist, 2015. "What Russia wants. From cold war to hot war." February 12, 2015. Retrieved November 7, 2017 from: https://www.economist.com/news/briefing/21643220russias-aggression-ukraine-part-broader-and-more-dangerous-confrontation

The Foreign Policy Concept of the Russian Federation. Approved by the President of the Russian Federation Vladimir Putin on November 30, 2016. Retrieved May 13, 2019 from: https://www.rusemb.org.uk/rp_insight/

The Military Doctrine of the Russian Federation. Embassy of the Russian Federation to the United Kingdom and Northern Ireland. Approved by the President of the Russian Federation on 25 December, 2014. No. Pr.-2976. Retrieved November 8, 2017 from: https://rusemb.org.uk/press/2029

The Wall Street Journal. 2019. "In Germany, a Cold War Deal to Host U.S. Nuclear Weapons Is Now in Question.” Accessed February 42012 from: https://www.wsj.com/articles/ingermany-anger-at-trump-throws-cold-war-nuclear-pact-into-question-11549976449

US Department of State. Treaty Between the United States of America and The Union of Soviet Socialist Republics on The Limitation of Anti-Ballistic Missile Systems (ABM Treaty) Retrieved July 31, 2018 from: https://www.state.gov/t/avc/trty/101888.htm

US Department of State 2019. U.S. Intent to Withdraw from the INF Treaty February 2, 2019. Retrieved May 14, 2019 from: https://www.state.gov/secretary/remarks/2019/02/288722.htm

Vinokurov, E., Y. 2005. The enclave specific vulnerability of Kaliningrad. In Liuhto, K. (ed). Kaliningrad 2020. Its future competitiveness and role in the Baltic Sea economic region. University of Turku, Finland. Retrieved July 27, 2018 from: 
http://www.utu.fi/fi/yksikot/tse/yksikot/PEI/raportit-jatietopaketit/Documents/Liuhto_72005.pdf\#page $=58$

Walt, S. M. 1997. “The progressive power of realism.” American Political Science Review 91 (4): 931-935.

Zęgota, K. (2018). The Kaliningrad Oblast: An Area of Cooperation or Conflict of Interests between the Russian Federation and the West. In Oldberg, I. (ed). Marketplace or military bastion? Kaliningrad between Brussels and Moscow. UI paper. No. 3. 2018. Published by the Swedish Institute for International Affairs. https://www.ui.se/globalassets/ui.seeng/publications/ui-publications/2018/ui-paper-no.-3-2018.pdf

Zeit online 2018. "Putin warnt vor neuem Wettrüsten." Retrieved May 14, 2019 from: https://www.zeit.de/politik/ausland/2018-10/abruestungsvertrag-russland-wladimir-putin-infeuropa-wettruesten 